\title{
Efficiently Removal of Copper and Cadmium from Wastewater using Activated Carbon Produced from Moringa oleifera Bark
}

\author{
Md. Shahin Azad ${ }^{1,2}$, Mohd Sukri Hassan ${ }^{1,+}$, Syaza Azhari ${ }^{1}$, \\ ${ }^{1}$ Department of Industrial Chemical Technology \\ Faculty of Science \& Technology, University Sains Islam Malaysia (USIM), \\ Nilai, Negeri Sembilan, Malaysia \\ ${ }^{2}$ Department of General Educational Development, \\ Faculty of Science \& Information Technology, Daffodil International University (DIU), \\ Dhanmondi, Dhaka, Bangladesh \\ M. Shahinuzzaman ${ }^{3}$ \\ ${ }^{3}$ Department of Chemical Sciences, \\ Faculty of Science and Technology, Universiti Kebangsaan Malaysia, \\ Bangi 43600, Selangor, Malaysia
}

\begin{abstract}
Moringa oleifera is a multipurpose tree. The main aim of this study was to use the Moringa oleifera bark with low doses as an adsorbent for the maximum removal of copper $(\mathrm{Cu})$ and cadmium $(\mathrm{Cd})$ from wastewater. There are some vital parameters which influence adsorption process such as contact time, adsorbent dose, initial concentration and $\mathrm{pH}$ were investigated. The activated carbon of Moringa oleifera bark with surface area of $439.2309 \mathrm{~m}^{2} / \mathrm{g}$ and pore volume of $0.189245 \mathrm{~cm}^{3} / \mathrm{g}$ was achieved at $700{ }^{\circ} \mathrm{C}$ and used $(10 \%)$ zinc chloride and $(0.5 \mathrm{M})$ sulfuric acid as an activating agent to char ratio (5:1). The copper $(\mathrm{Cu})$ was fully eliminated $(\mathbf{1 0 0 \%})$ from aqueous solution within $10 \mathrm{~min}$ while cadmium (Cd) also was significantly removed using $0.25 \mathrm{gm} / \mathrm{L}$ of adsorbents. The Freundlich isotherm, pseudo- second order kinetic equations were well fitted with a correlation coefficient of $(0.993$ and 1$)$ for copper and $(0.953$ and 0.999$)$ for cadmium respectively. We observed that at $\mathrm{pH} 11$, adsorbents showed maximum adsorption capacity. Therefore, it can be used as a potential, eco-friendly non-toxic, cost effective application for wastewater treatment. Finally, this works also focused regeneration of adsorbents using solvents for further highest reuse of it.
\end{abstract}

Keywords - Moringa oleifera bark; Activated carbon; Adsorption; Heavy metal; Wastewater treatment

\section{INTRODUCTION}

Pure water has essential mineral elements which are very important for human beings and animals. Every cell of alive body needs pure water to continue normal activities. Pure fresh water does not appear in nature available due to contain huge contaminants in the environment. Many pollutants especially inorganic in nature like heavy metal contaminate water eco-systems and create serious problems. Toxic metal compounds contaminate not only surface water but also ground water. Most of the heavy metal come from industry. Major toxic elements are lead $(\mathrm{Pb})$, copper $(\mathrm{Cu})$, nickel $(\mathrm{Ni})$, cadmium $(\mathrm{Cd})$, chromium $(\mathrm{Cr})$ etc. Wastewater mainly comes from municipal, agricultural and industrial activity [1]. Many heavy metals are released from paint, ceramics and dyes industries [2]. According to WHO (1997), any change in the physical, chemical and biological properties of water may be dangerous effect on human beings and animals. This is known as 'water pollution'. Pollute water contain various poisonous agents such as heavy metal, colour, dyes, grease, oil and bacteria etc. The presence of these agents in water system may cause various water borne diseases. Human and animal use water for several purposes. But the water purity level is very crucial. For this reason, it can direct effect on health. The traditional wastewater treatment is used aluminium sulphate (alum) and calcium hypochlorite. But it's very costly for developing country. Wastewater is very harmful for human body and environment [3]. Cadmium (Cd) is released from zinc smelting, and paint sludge. Lead is released from lead batteries and ceramics [4]. Metal ions are being importance pollutants due to their toxicity [5]. Toxic heavy metal is very dangerous for non-biodegradability. These all gather in living organism causes appear disease \& sicknesses [6]. This poisonousness may influence at nervous systems and other vital organs [7].

There are several conventional methods like physical, biological and chemical methods for eliminating heavy metal from wastewater $[8,9]$. Adsorption is one of the vital process for toxic metal removal from wastewater [10]. Most of the water treatment processes are very costly in the global [11, 12]. Adsorption is a physico-chemical phenomenon which can adsorb contaminants from wastewater by surface chemistry of adsorbents. Normally, Commercial activated carbon is used as adsorbent in adsorption process for the wastewater treatment due to high adsorption capacity and environmental friendly [13] but it is very costly process [14] Therefore, it is essential to find natural alternatives that is cost effective and available. Natural by-products are the essential source for adsorbents. There are some polar 
functional groups. Most of the vital groups are hydroxyl, aldehydes, carboxylic, and ketones [2]. These groups can fix heavy metals by providing an electron pair [5]. Several agricultural waste like neem bark, Moringa Oleifera bark, rice husk have binding capacity that adsorb pollutant from aqueous solution. Adsorption capacity can be developed using chemically activated adsorbents. Adsorption method is very popular for effectiveness, cheap and available every place [15].

Moringa oleifera $(M O)$ is one of these alternatives for wastewater treatment $[16,17]$. It has been found useful in nutrition, water purification, and industrial applications. It's also called "Drumstick" or Ben oil tree and is a medium sized medicinal tree. It is available in south Asia, Africa, and South America. Leaves and seeds of $M O$ are very frequently used for water treatment [18]. It has no side effects. It is non-toxic and ecological material [19]. MOCR (Moringa oleifera cake residue) don't need further preparation for water purification process [20]. MO seed has excellent coagulant properties to purify contaminated water [21]. It can remove turbidity from wastewater and also has antimicrobial properties [22]. Moringa oleifera bark have non-toxic natural organic polymer such as alkaloids, phenols and glycosides which have been employed as an effective adsorbent for purification of wastewater. Many researchers have used Moringa oleifera seeds, leaves and fruits for water decontamination. The seeds of moringa oleifera contain polyelectrolytes which can bind contaminants. Moringa oleifera have the valuable effect as medicine, nutrition, water management and so on [15]. Leaves, fruits, roots of $M O$ are used as vegetables [23] and source of vitamins $[24,25]$. Other sides, various parts of $M O$ such as stem, bark, and roots have antimicrobial activities $[26,27]$. Moringa oleifera leaves have both macro- and micronutrients such as $\beta$ carotene, protein etc. It's leave possesses hypolipidaemic and antiathersclerotic activities [28]. Moringa oleifera pods have free radicals scavenging abilities [29]. Its act as a natural antioxidant [30] like some other plants which are reported as natural sources of antioxidants [31, 32]. Moringa oleifera bark also remove heavy metal like $\mathrm{Ni}$ (II) from wastewater [33]. It has maximum adsorption capacity of $30.38 \mathrm{mg} / \mathrm{g}$ [34]. Moringa oleifera is a low-cost plant and biodegradable sludge. A central carbon atom of glucosinolate is bonded to thioglucose group with a sulfur atom and also bonded to a sulfate group with a nitrogen atom. These functional groups can be used to remove contaminants from wastewater. Finally, the major objective of this experiments was to use activated carbon of the Moringa oleifera bark with low doses as an adsorbent to successfully eliminate copper $(\mathrm{Cu})$ and cadmium $(\mathrm{Cd})$ from wastewater.

\section{EXPERIMENTAL}

\section{A. Sample collection and preparation}

Moringa oleifera bark were collected from natural sources near the University Sains Islam Malaysia (USIM) campus, in-front of Akasia Park, Bandar Baru Nilai, Negeri Sembilan, Malaysia and washed with distilled water. The barks were sun dried for 6 hours then it washed with distilled water to remove dirt from its surface and dried in an oven at $110{ }^{\circ} \mathrm{C}$ for 13 hours. The Moringa oleifera bark were reduced into smaller particle sizes using mortar \& pestle as well as blinder. The samples (100 g) were then chemically activated using $500 \mathrm{ml}$ zinc chloride $\left(10 \% \mathrm{ZnCl}_{2}\right)$ and sulfuric acid $\left(0.5 \mathrm{M} \mathrm{H}_{2} \mathrm{SO}_{4}\right)$ with ratio of $1: 5$ for 12 hours. Then the samples were dried in the oven at $110{ }^{\circ} \mathrm{C}$ for $12 \mathrm{hrs}$. It was grinded and sieved at $400 \mu \mathrm{m}$. Then the sample was kept in the desiccator for further use. The precursor was placed in the furnace at $700{ }^{\circ} \mathrm{C}$ with heating rate of $10{ }^{\circ} \mathrm{C} / \mathrm{min}$ for $60 \mathrm{~min}$. During the carbonization process, purified nitrogen was flown. It was cooled in normal temperature. This activated carbon samples were washed severally with distilled water. The washed samples were dried in oven at $110{ }^{\circ} \mathrm{C}$ for 15 hours. These were then sieved with a sieve of $400 \mu \mathrm{m}$. The activated carbon samples were kept in a polypropylene bottle to avoid moisture. These prepared activated carbon of Moringa oleifera bark were used for the experiments as the adsorbent in adsorption process.

\section{B. Instrumentation}

Water distillatory (2108, GLF, Germany), pH meter (3510, Genway), analytical balance (CP 2245, Sartorius, USA.), Oven, Furnace, Shaker and Blinder are used during this study. The concentration of before and after adsorption of solution were determined using Atomic absorption spectrophotometer (AAS-240 FS AA, USA). FTIR spectra were determined using (PERKIN ELMER FTIR Model 1600, Greenville, SC, USA) where the spectra were obtained ranging $4000-400 \mathrm{~cm}^{-1}$. Micro porosity of outer surface of adsorbents and pore size were obtained using Scanning electron microscope (SEM-HITACHI SU 6600, Tokyo, Japan) and Brunauer-Emmett-Teller (BET : BELSORPMINI, Chiba, Japan).

\section{Chemicals}

Almost chemicals were of analytical grading and were directly used without further purification. The chemicals such as $\mathrm{CuSO}_{4} .5 \mathrm{H}_{2} \mathrm{O}(>99 \%), \mathrm{Cd}\left(\mathrm{NO}_{3}\right)_{2} .4 \mathrm{H}_{2} \mathrm{O}(99 \%), 0.5 \mathrm{M} \mathrm{HCl}$ (70\%), 0.5 $\mathrm{M} \mathrm{H}_{2} \mathrm{SO}_{4}$ (>98\%), 0.5 $\mathrm{M} \mathrm{HNO}_{3}(70 \%), 1 \mathrm{~N} \mathrm{NaOH}$, $0.05 \mathrm{M} \mathrm{NaNO} \mathrm{Naffer}_{3}$ buf(10\%) $\mathrm{ZnCl}_{2}$, were purchased from Merck, Germany. All chemicals were used as received.

\section{Adsorption Experiments}

Stock solution of metal were made by dissolving metal nitrate $\left(\mathrm{Cd}\left(\mathrm{NO}_{3}\right)_{2}\right)$ and sulphate salts $\left(\mathrm{CuSO}_{4}\right)$ in deionized water. Different concentrations were obtained from the stock solutions. This study was conducted by adding $0.25 \mathrm{gm} / \mathrm{L}$ activated carbon in solutions. Flask with adsorbents are placed in a shaker at room temperature $\left(25 \pm 2{ }^{\circ} \mathrm{C}\right)$ with 200rpm speed for 2 hours. The $\mathrm{pH}$ was controlled at $11 \mathrm{using}$ $0.1 \mathrm{~N} \mathrm{NaNO}_{3}$ buffer solution to get best adsorption capacity for this experiment but to observe the effect of $\mathrm{pH}$ of the solution were adjusted ranging from $2-12$ by $0.1 \mathrm{~N}(\mathrm{HCl} \&$ $\mathrm{NaOH}$ ) solutions. Then after 10, 20, 30, 60 and 120 minutes the samples were taken and filtered with whatman filter paper. It was analysed using Atomic Adsorption Spectrophotometer (AAS). According to equation (1), the amount of adsorbate adsorbed on the adsorbent at equilibrium, qe $(\mathrm{mg} / \mathrm{g})$ was calculated and the percent removal of adsorbate was evaluated as expressed in equation (2) [35]: 
$q e=(\mathrm{Co}-\mathrm{Ce}) \mathrm{VI} W$

Where $C o$ and $C e(\mathrm{mg} / \mathrm{L})$ are the concentrations of solution at initial and at equilibrium time, respectively. $V$ is the volume of the solution (L) and $W$ is the mass of adsorbent used $(\mathrm{g})$ :

$$
\% \text { Removal }=(\mathrm{Co}-\mathrm{Ce}) \times 100 / \mathrm{Co} \text {. }
$$

Adsorption isotherm and Kinetics equation

The most commonly used adsorption isotherm models are those of Freundlich and Langmuir. In this work, Langmuir Model was tested and given as:

$q=q_{m} K_{\mathrm{q}} C$

$/ 1+K_{q} C$.......

Where $\mathrm{q}_{\mathrm{m}}=\mathrm{q}$ for a complete monolayer ( $\mathrm{g}$ adsorbate $/ \mathrm{g}$ sorbate), $\mathrm{K}_{\mathrm{q}}=\mathrm{a}$ coefficient $\left(\mathrm{kg} / \mathrm{m}^{3}\right.$ or $\left.\mathrm{g} / \mathrm{cm}^{3}\right)$. Taking reciprocal and rearranging equation (3) gives:

$1 / q=1 / q_{m}+1 / \mathrm{K}_{\mathrm{q}} q_{m} C$

A plot of $1 / \mathrm{q}$ versus $1 / \mathrm{C}$ gives a straight line of slope $1 / \mathrm{K}_{\mathrm{q}} \mathrm{q}_{\mathrm{m}}$ and an intercept of $1 / \mathrm{q}_{\mathrm{m}}$. Equation (4) could be expressed in a standard format as given bellow:

$$
C_{e} / q_{e}=1 / \mathrm{Q}_{\mathrm{b}}{ }^{0}+C_{e} / \mathrm{Q}_{\mathrm{o}}
$$

Where $C_{e}$ is the equilibrium concentration of sorbate $\left(\mathrm{mg} / \mathrm{liter}\right.$ or $\mathrm{ppm}$ or $\mathrm{g} / \mathrm{cm}^{3}$ or $\left.\mathrm{mol} / \mathrm{m}^{3}\right), \mathrm{q}_{\mathrm{e}}$ is the amount adsorbed at equilibrium (mgg-1) while $\mathrm{Q}_{\mathrm{o}}$ and $\mathrm{b}$ are the Langmuir constants related to capacity (mgg-1) and energy respectively. A plot of $\mathrm{C}_{\mathrm{e}} / \mathrm{q}_{\mathrm{e}}$ Versus $\mathrm{C}_{\mathrm{e}}$ gives a straight line of slope $1 / Q_{\mathrm{o}}$ and intercept of $1 / \mathrm{Q}_{\mathrm{b}}{ }^{0}$. However, a pseudo-first order kinetic model as recommended by [6] is given as:

$d q t d t=\mathrm{K}_{1}\left(q_{e}-q_{t}\right)$

Where $\mathrm{q}_{\mathrm{e}}$ and $\mathrm{q}_{\mathrm{t}}$ are adsorption capacity terms at equilibrium and at time $\mathrm{t}$ respectively $(\mathrm{mg} / \mathrm{g}), \mathrm{K}_{1}$ is the rate constant. Integrating equation (6) with the boundary conditions gives: $\log \left(q_{e}-q_{t}\right)=\log q_{e^{-}}$

$\mathrm{K}_{1} t / 2.303$

A plot of $\log \left(\mathrm{q}_{\mathrm{e}}-\mathrm{q}_{\mathrm{t}}\right)$ versus $\mathrm{t}$ is a linear relationship from where $\mathrm{K}_{1}$ and $\mathrm{q}_{\mathrm{e}}$ can be determined respectively. In a similar manner the pseudo-second order model is expressed as:

$d q t d t=\mathrm{K}_{2}\left(q_{e}-q_{t}\right)^{2}$

Where $\mathrm{K}_{2}$ is the pseudo- second order rate constant of adsorption. After integration:

$1 / q_{e}-q_{t}=1 / q_{e}+\mathrm{K}_{2} t$

The linearized form of equation (9) is:

$t / q_{t}=1 / K_{2} q_{e}^{2}+\left(1 / q_{e}\right) t$.
Again, a plot of $\mathrm{t} / \mathrm{q}_{\mathrm{t}}$ versus $\mathrm{t}$ will give a linear relationship with $1 / \mathrm{q}_{\mathrm{e}}$ and $1 / K_{2} q_{\mathrm{e}}{ }^{2}$ as the slope and intercept respectively.

\section{RESULT AND DISCUSSION}

\section{A.Characterization of Activated carbon}

\section{1) Surface Morphology}

Figure 1(a) shows the FESEM micrographs of the Moringa oleifera bark activated carbon before adsorption under 1000x magnification while (b) is the micrographs of the activated carbon after adsorption under 30000x magnifications. There were presence many hole on its surface. These holes were the available pores, where copper and cadmium molecules were to be captured from wastewater solution. Large and well-developed pore were obtained from prepared activated carbon under optimum condition (at 700 ${ }^{\circ} \mathrm{C}$ temperature, activation time $60 \mathrm{~min}$ as well as char: $\mathrm{ZnCl}_{2}$ and $\mathrm{H}_{2} \mathrm{SO}_{4}$ impregnation ratio 1:5). It might be occurred due to use chemically activity agent. The adsorb metal molecules got to fill the pores from adsorbent surface to inner pore and at last its bind at the available sites on their surface. Surface area and pore volume development could be happened also during pyrolysis process. This produced well developed pore was the important factor to adsorb the maximum heavy metal from wastewater. Both micrographs presented with the morphological changes of the carbon materials during before and after adsorption processes. Figure 1(b) shows after adsorption most of the pore of activated carbon has been filled-up by heavy metal. After carbonization was performed under inert condition, some irregular holes and pores were developed on the surfaces of the chars. This was due to the sudden burst of the thermal expansion from pyrolysis. Pore development in the char during pyrolysis was important. Since it would develop the surface area and pore volume of the activated carbon after the activation process [36]. The activated carbon formed irregular, large caved-in shaped cavities on its surface. The adsorption of cadmium at the surface of adsorbents might be physiosorption and copper could be occurred chemisorption.

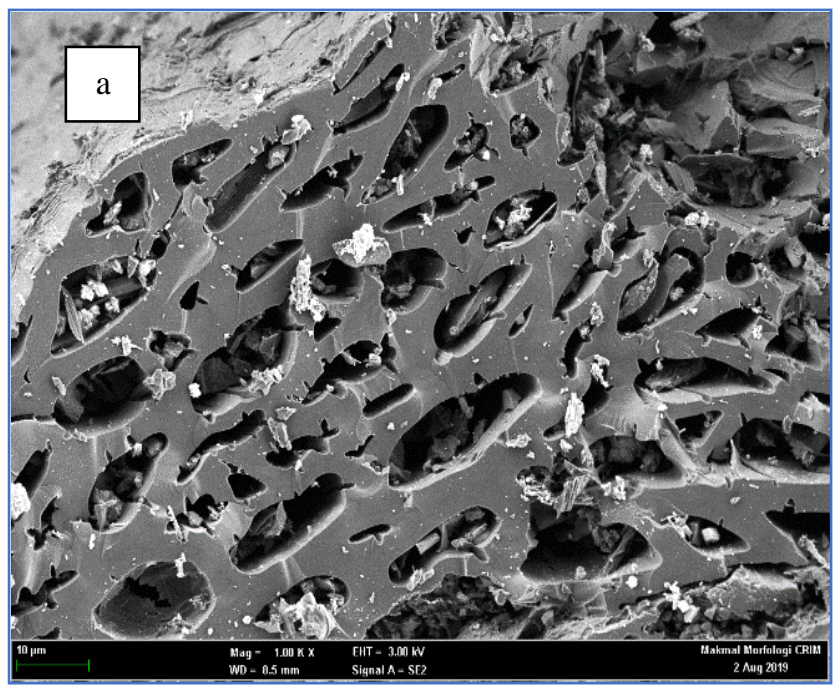




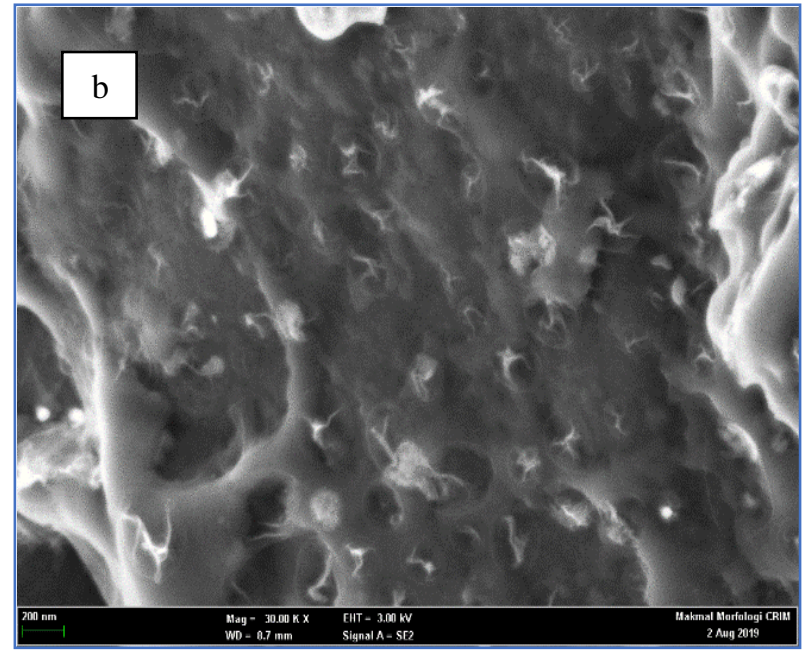

Fig. 1. FESEM micrograph of Moringa oleifera bark (Activated carbon); (a) before and (b) after adsorption

2) Surface Area and Porosity

In this study, the surface area and porosity of the prepared activated carbon were analysed. The BET surface areas were found to be relatively high. The smallest pore was surface area of $396.9325 \mathrm{~m}^{2} / \mathrm{g}$ and the largest was $435.1738 \mathrm{~m}^{2} / \mathrm{g}$ when pyrolysis was done at $700{ }^{\circ} \mathrm{C}$. The total pore volumes measured as higher for single point and micropore were $0.189245 \mathrm{~cm} 3 / \mathrm{g}$ and $0.153732 \mathrm{~cm} 3 / \mathrm{g}$ respectively. The development of more surface area and pores in activated carbon treated with acid solution is likely to be due to the elimination of impurities on the surface and/or in the pores. The pore size for single pore (diameter) and micropore (width) were analysed as $68.488 \AA$ and $17.234 \AA$. Activated carbon can consist of mineral matter up to $15 \%$ in the form of ash content, which clogs up in the pores (Aji et.al. 2015). According to [37], the minerals are observed as unwanted contaminants such as $\mathrm{N}, \mathrm{P}, \mathrm{Si}, \mathrm{Na}, \mathrm{K}, \mathrm{Zn}$ and $\mathrm{Fe}$. In order to purify the prepared activated carbon and to remove the contaminants, acid solution is usually used during washing part and in further treatment. These inorganic elements could be removed from activated carbon with acid $\left(\mathrm{H}_{2} \mathrm{SO}_{4}\right.$ and $\mathrm{ZnCl}_{2}$ ) treatment in order to reduce the ash content.

\section{3) Surface Functional Groups}

The FTIR spectra analysis is essential to determine various surface function of Moringa oleifera bark( MOB), as shown in Figure 2. The FTIR spectrum of MOB shown broad peaks at $3371 \mathrm{~cm}^{-1} \mathrm{~cm}-1$ which are attributed to the $\mathrm{O}-\mathrm{H}$ stretching band of hydroxyl group of phenols and alcohols in lignin and cellulose of MOB before adsorption process $[38,39]$. The distinct peaks observed in $3183 \mathrm{~cm}^{-1}$ are detected to the $\mathrm{C}-\mathrm{H}$ stretching vibrations of aliphatic hydrocarbons [40]. The band at a range of 1615-1430 cm- 1 is attributed to $\mathrm{C}=\mathrm{C}$ stretching vibrations, and the peak $<900$ cm- 1 results of C-H (out of plane) confirm the presence of aromatic ring in the adsorbent [41]. The peaks at $1126 \mathrm{~cm}^{-1}$ may denote the presence of stretching $\mathrm{C}-\mathrm{O}$, which includes compounds such as carboxyl groups that provide adsorption sites for the metal ions.
Oxygen functional groups of ketone $(\mathrm{C}=\mathrm{O})$ was not detected in the prepared activated carbon. The presence of oxygen (C-O) functional group peak was detected at 1126 $\mathrm{cm}^{-1}$ on the surface of activated carbon. It was expected to indicate the polarity. After adsorption of heavy metal, peaks were detected with slightly shifting at $3500 \mathrm{~cm}^{-1}(\mathrm{O}-\mathrm{H}), 1432$ $\mathrm{cm}^{-1}$ (C-O), $1123 \mathrm{~cm}^{-1}$ (C-O) stretching, peak for $3125(\mathrm{C}-\mathrm{H})$ stretching due to bind with metal.

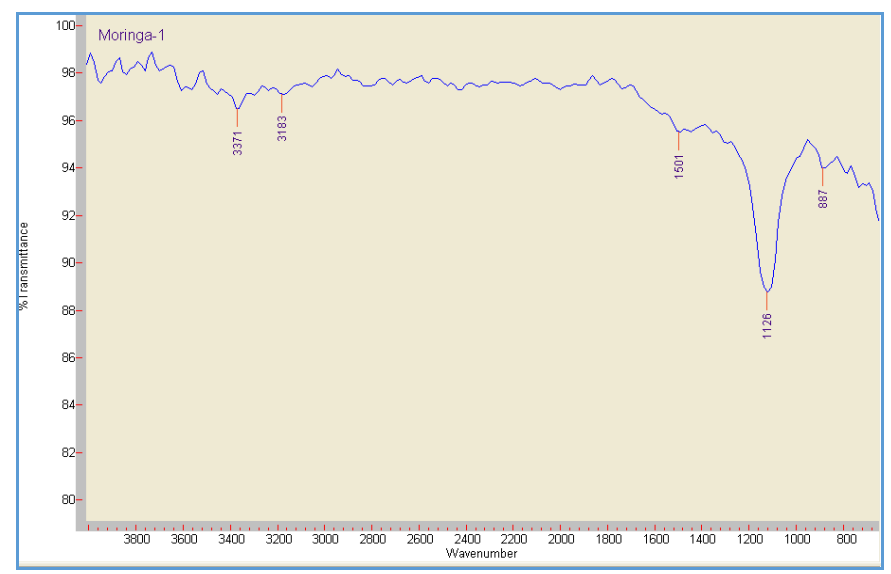

Figure 2. FTIR spectra before metal ion adsorption on Moringa oleifera

\section{B. Equilibrium Studies}

The equilibrium curve of copper and cadmium for the Moringa oleifera activated carbon was studied and shown in Figure 3. The copper curve shows a concave downward shape due to high affinity between absorbate and activated carbon. The contaminant metals were cationic form. The adsorption mechanism could be occurred by ion exchange or electrostatic forces due to possess oxygen containing group $(\mathrm{COOH})$ on surface of adsorbents. So, with increasing the oxygen containing group of adsorbents, the quantity of adsorbate also increased. The amount of adsorbate ranged from $3.98 \mathrm{mg} / \mathrm{g}$ to $20.45 \mathrm{mg} / \mathrm{g}$ within $10 \mathrm{~min}$ for ranging initial concentration (1-5) $\mathrm{mg} / \mathrm{L}$ of copper salt solution were observed where final concentration obtained zero $\left(\mathrm{C}_{\mathrm{f}}=0\right)$ and after $120 \mathrm{~min}$ the quantity of adsorbate ranged from $3.98 \mathrm{mg} / \mathrm{g}$ to $20.09 \mathrm{mg} / \mathrm{g}$ respectively. On contrast, for cadmium salt solution adsorbed amount were obtained from $4.36 \mathrm{mg} / \mathrm{g}$ to $19.65 \mathrm{mg} / \mathrm{g}$ at $10 \mathrm{~min}$ with final concentration as $\mathrm{C}_{\mathrm{f}} \sim 0$ and at equilibrium state the quantity of adsorbent shown $3.4 \mathrm{mg} / \mathrm{g}$ to $11.42 \mathrm{mg} / \mathrm{g}$. Therefore, at $700{ }^{\circ} \mathrm{C}$ activation temperature and char: zinc chloride \& sulfuric acid with ratio $1: 5$, the activated carbon showed optimum adsorptive capacity. The results showed a rapid uptake of adsorbate molecules onto the surface of the adsorbent at the first $10 \mathrm{~min}$, and then shown slight desorption and again a slower uptake up to $120 \mathrm{~min}$. The reason for this behavior is that the adsorptive site becomes loaded as molecules adhere to the surface of the carbon structure. The values however greatly depend on the equilibrium concentration of the effluent with the adsorbent. 


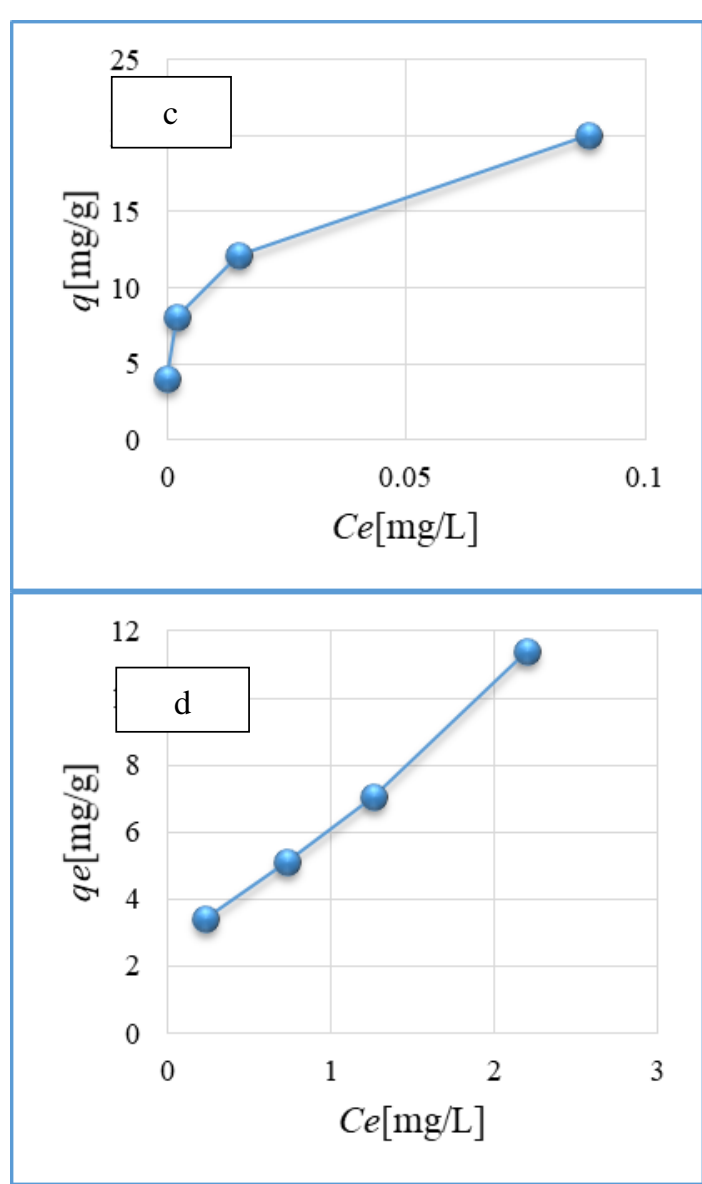

Figure 3. Equilibrium curve for (c) $\mathrm{Cu}^{2+}$ and (d) $\mathrm{Cd}^{2+}$ using optimum value obtained

C.Langmuir and Freundlich isotherms

Langmuir isotherm expressed monolayer of the metal ions are designed on adsorbent. The experimental $\mathrm{q}_{\max }$ for Moringa oleifera are found to be 20.43 and 17.01 for $\mathrm{Cu}$ and $\mathrm{Cd}$ comparable with theoretically calculated $\mathrm{q}_{\max }$ as given in Table 1 . The higher value of $b$ is described the affinity of the adsorbent to adsorb metal ions. The value of $\mathrm{q}_{\max }$ can also be considered as the total number of active sites of adsorbents for adsorption. According to the Table 1, the affinity order of Moringa oleifera is like $\mathrm{Cu}>\mathrm{Cd}$. From the plot of $\log \mathrm{q}$ against $\log \mathrm{Ce}$ were obtained the constant $\mathrm{K}$ and $1 / \mathrm{n}$. $\mathrm{K}$ is indicated the strength of adsorption. Lower value of $\mathrm{K}$ designates the more adsorption [42]. Another constant $1 / \mathrm{n}$ is indicated the adsorption intensity. Data would be favourable when $\mathrm{n}$ value is $(1<\mathrm{n}<10)$. All data of Moringa oleifera are well fitted of Langmuir isotherm and Freundlich isotherm. The mean adsorption energy (E) can describe about adsorption properties. It can be calculated from the D-R isotherm model [43]. If the values of $\mathrm{E}<8 \mathrm{kJmol}-1$, it follows physical adsorption. When the value of $\mathrm{E}$ is ranging $8-16$, it follows chemical adsorption. From the Table 1 of adsorption energy values suggested that Moringa oleifera indicates a physical adsorption for cadmium $(\mathrm{Cd}, \mathrm{E}=2.61)$ metal ions and copper $(\mathrm{Cu}, \mathrm{E}=9.8)$ adsorbed by chemical adsorption process.
The experimental data were well fitted into Freundlich isotherm and represented in Figures 5. For Langmuir isotherm, plot of Ce/qe against $\mathrm{Ce}$ shown linear relationship with $\mathrm{R}^{2}=0.989$ of copper and $\mathrm{R}^{2}=0.801$ of cadmium. For Freundlich isotherm, plot of $\log$ qe against $\log$ Ce gave also linear relationship with $\mathrm{R}^{2}=0.993$ of copper and $\mathrm{R}^{2}=0.953$ of cadmium. The Freundlich plot and the Langmuir plot fitted favourably well with the isotherms because the value of $R_{L}$ obtained from slope were 0.0021 for copper and 0.22 for cadmium [favourable when $\left(0<\boldsymbol{R}_{\boldsymbol{L}}<1\right)$ ]. For Freundlich isotherm, a value of $\mathrm{n}(4.22)>1$ for copper and $1.91>1$ for cadmium (favourable when $1<\mathrm{n}<10$ ) obtained represents a favourable condition following the works of Mckay and Ho (1998).

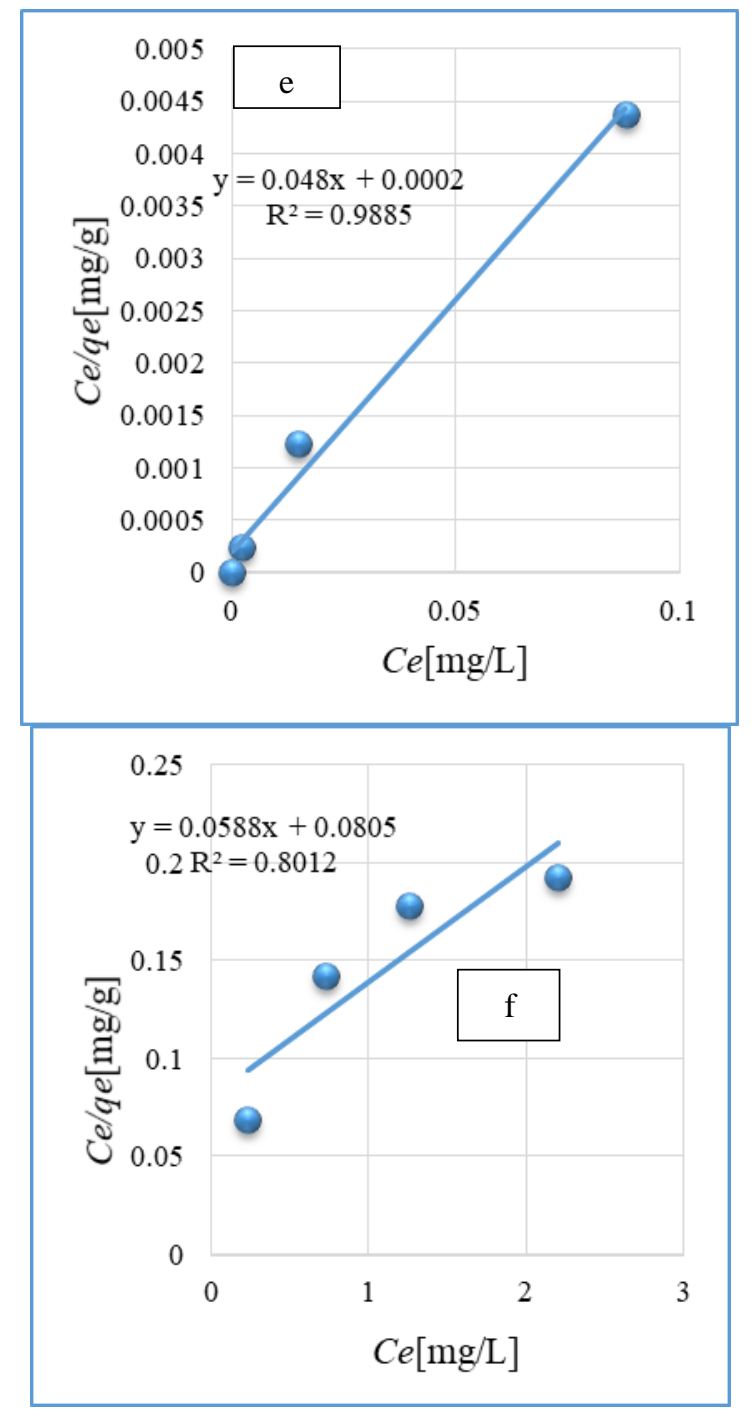

Figure 4. Langmuir plot for activated carbon using optimum value for (e) $\mathrm{Cu}^{2+}$ and (f) $\mathrm{Cd}^{2+}$ adsorption 


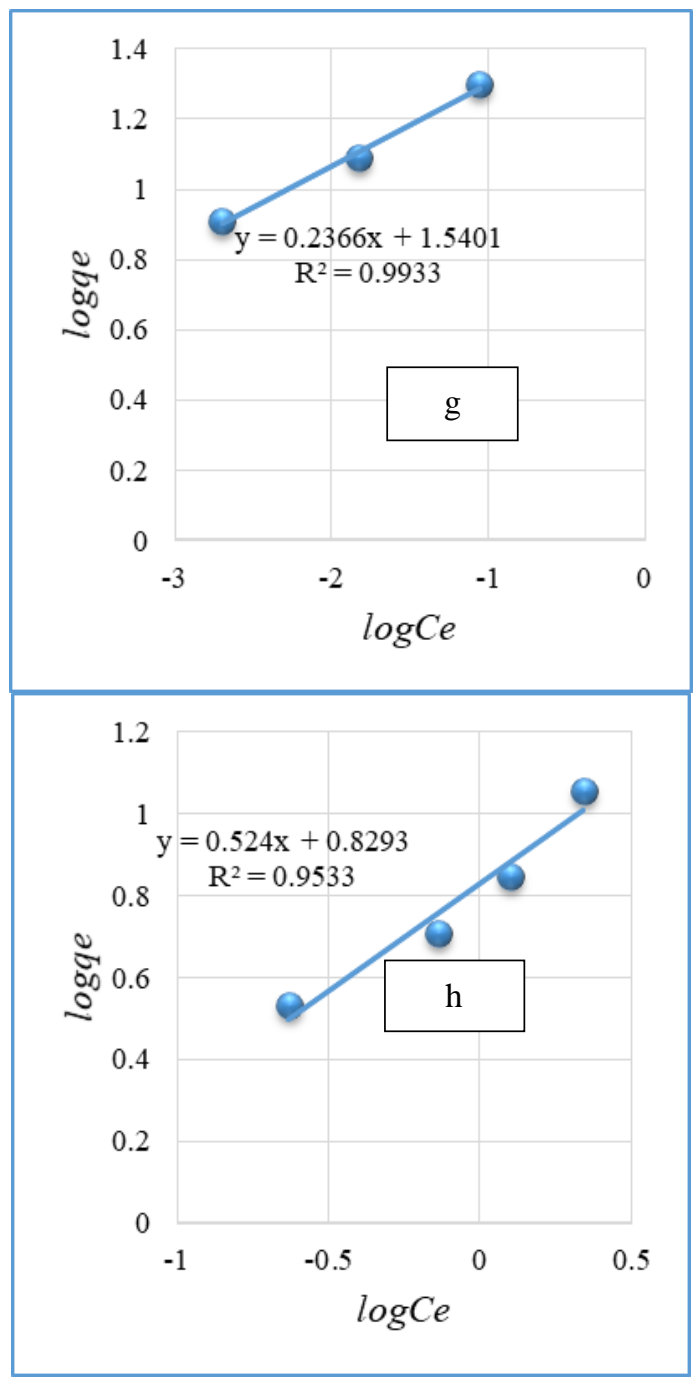

\section{D.Adsorption kinetic studies}

The correlation coefficient, rate constants, calculated metal-uptake and other kinetic constant from the three models studied were shown in Table 2 . These calculated kinetic constants indicated pseudo-second-order kinetic with highest correlation coefficient $R^{2}$ to fit best. Kinetic does not apply to pseudo-first-order and inter-particle diffusion model. Equally, calculated metal-uptake in pseudo-first-order kinetic is by far less than one obtained from experiment $(q \mathrm{e}(\mathrm{cal})<<q$ e $(\exp ))$. Whereas, in pseudo-second-order kinetic, the metal-uptake calculated is closer to that obtained from experiment. This further confirms fitness of kinetic studies with pseudosecond-order.

If the linearity was achieved and the line passes through the origin, it indicates the internal diffusion is the slowest step in the adsorption process. From Figure 6, graph line for copper and cadmium of Moringa oleifera were not linearity and did not pass through the origin. It is indicated that the adsorption process was controlled by film diffusion [44]. From the Figures 7 and 8 of this finding, the pseudo-second order well favoured the adsorption process with a regression correlation $\mathrm{R}^{2}$ of 1 for copper and 0.999 for cadmium while the pseudo first order kinetic coefficient $\mathrm{R}^{2}$ got 0.963 for copper and 0.864 for cadmium. The correlation coefficient was well fitted for pseudo-second order contrast of first order and inter-particle diffusion. Therefore, the adsorption and kinetics of $\mathrm{Cu}^{2+}$ ions and $\mathrm{Cd}^{2+}$ could be well approximated adequately by the second order model.

Fig. 5 Freundlich plot for activated carbon using optimum value for $(\mathrm{g}) \mathrm{Cu}^{2+}$ and (h) $\mathrm{Cd}^{2+}$ adsorption

TABLE 1 Comparison table for Langmuer, Freundlich and Dubininraduchkevich of Moringa oleifera activated carbon

\begin{tabular}{|c|c|c|c|c|c|c|c|c|c|}
\hline \multirow[b]{2}{*}{ Heavy } & \multicolumn{3}{|c|}{ Langmuir model } & \multicolumn{3}{|c|}{ Freundlichmodel } & \multicolumn{3}{|c|}{ Dubinin-Radushkevich } \\
\hline & $R^{2}$ & $q_{\max }$ & $b$ & $R^{2}$ & $1 / n$ & $\boldsymbol{K}$ & $R^{2}$ & $q_{\max }$ & E[kJmol] \\
\hline Metal & & {$[m g / g]$} & [Lmg-1] & & & & & {$[m g / g]$} & \\
\hline $\mathrm{Cu}$ & 0.989 & 20.43 & 162.07 & 0.993 & 0.24 & 34.7 & 0.949 & 22.07 & 9.80 \\
\hline $\mathrm{Cd}$ & 0.801 & 17.01 & 0.73 & 0.953 & 0.52 & 6.75 & 0.774 & 8.94 & 2.61 \\
\hline
\end{tabular}




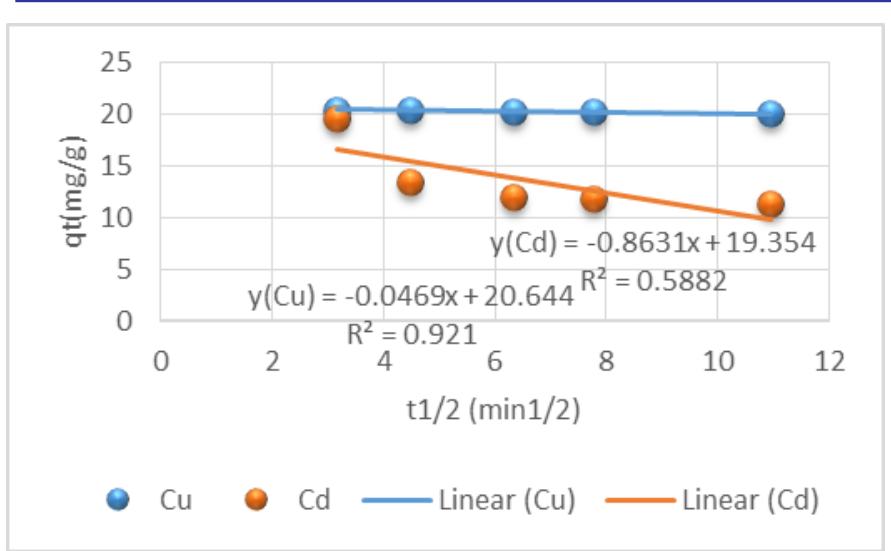

Fig. 6 Inter-particle diffusion for copper and cadmium of Moringa oleifera

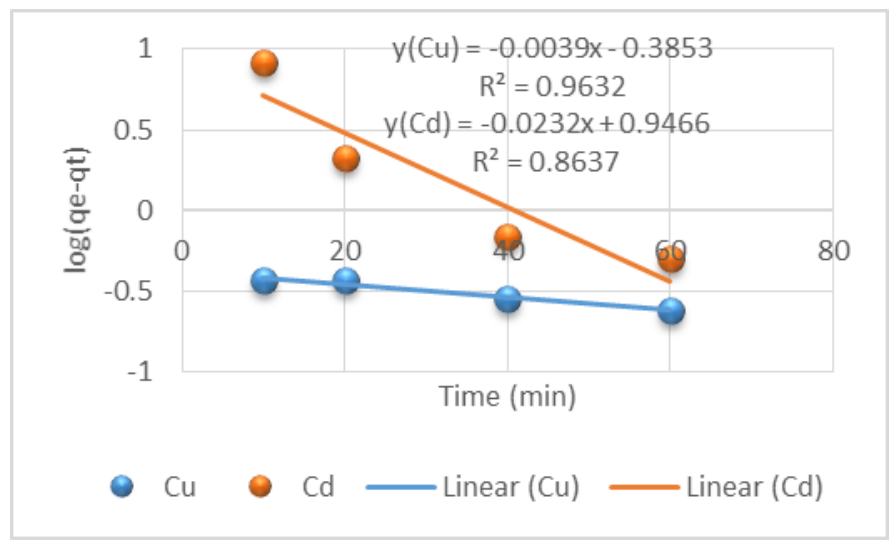

Fig.7 Pseudo first order kinetic adsorption model for $\mathrm{Cu}^{2+}$ and $\mathrm{Cd}^{2+}$ from optimum value obtained

TABLE $21^{\text {st }}, 2^{\text {nd }}$ order and inter-particle diffusion constant values comparison of Moringa oleifera activated carbon

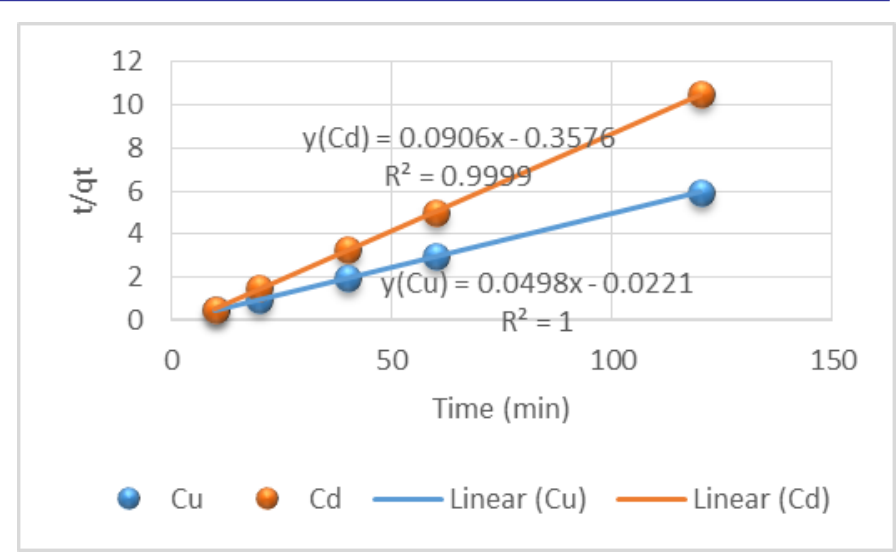

Fig. 8 Pseudo second order kinetic model for $\mathrm{Cu}^{2+}$ and $\mathrm{Cd}^{2+}$ adsorption from optimum value obtained

\begin{tabular}{|c|c|c|c|c|c|c|c|c|c|}
\hline \multirow[t]{2}{*}{$\begin{array}{l}\text { Heavy } \\
\text { Metal }\end{array}$} & \multirow[t]{2}{*}{$\begin{array}{r}q_{\text {exp }} \\
\mathrm{mg} / \mathrm{g}\end{array}$} & \multicolumn{3}{|c|}{ First Order } & & cond $O_{1}$ & & \multicolumn{2}{|c|}{$\begin{array}{c}\text { Intra-Particle } \\
\text { Diffusion }\end{array}$} \\
\hline & & $R^{2}$ & $\begin{array}{c}q_{q a l} \\
m g / g\end{array}$ & $\begin{array}{c}k 1 \\
{\left[\mathrm{~min}^{-1}\right]}\end{array}$ & $R^{2}$ & $\begin{array}{c}q_{q a l} \\
m g / g\end{array}$ & $\begin{array}{l}\mathrm{K}^{2} \\
\min ^{-1} \\
{\left[\mathrm{gmg}^{-1}\right]}\end{array}$ & $\begin{array}{c}K d \\
{\left[\mathrm{mgl}^{-1} \min ^{-1 / 2}\right]}\end{array}$ & $R^{2}$ \\
\hline $\mathrm{Cu}$ & 20.09 & 0.963 & 2.43 & 0.009 & 1.00 & 20.08 & 0.112 & 0.047 & 0.929 \\
\hline $\mathrm{Cd}$ & 11.42 & 0.864 & 8.87 & 0.053 & 0.999 & 11.04 & 0.023 & 0.863 & 0.588 \\
\hline
\end{tabular}




\section{E. Effect of Initial concentration}

The effect of initial concentration for the removal of copper and cadmium from wastewater using activated carbon of Moringa oleifera shown as Figure 9. The initial concentrations were set at $1,2,3,5 \mathrm{mg} / \mathrm{L}$. It may be described from the graph that with increasing the initial concentration, the removal percentage of copper and cadmium from aqueous solution were decreased but the adsorption capacity of both metals also was increased using all activated carbon. Within $10 \mathrm{~min}$ for all initial concentration $(\mathrm{mg} / \mathrm{L})$, absolutely $(100 \%)$ percent of copper was removed and the adsorption quantity was $20.45 \mathrm{mg} / \mathrm{g}$. but after $120 \mathrm{~min}$ at equilibrium copper removal percentage was slightly decreased and obtained more than $98 \%$ as shown in Table 3. On contrast, the removal percentage of cadmium were $100 \%$ for concentration of $1 \&$ $2 \mathrm{mg} / \mathrm{L}$ and more than $96 \%$ for concentration of $5 \mathrm{mg} / \mathrm{L}$ in just $10 \mathrm{~min}$. but after equilibrium, the removal percentage of cadmium was decreased and obtained more than 56. This type of pattern suggested that it can be possible due to monolayer formation of pollutant on the adsorbent surface [45].

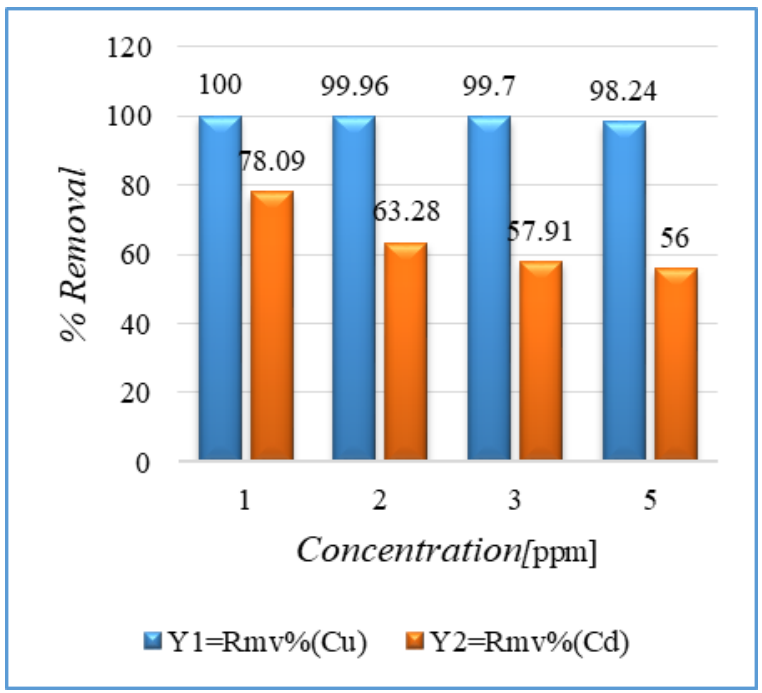

\section{F. Effect of Adsorption Time}

The adsorption experiments were necessary to define the contact time essential to touch the equilibrium position. The adsorption performance of copper and cadmium were conducted at time intervals $10-120 \mathrm{~min}$ as shown in Figure 10. Firstly, the amount of metal uptake was very good from 10 min to equilibrium state for copper but for cadmium after $10 \mathrm{~min}$ was decreased then steady with time till equilibrium state. After 120 minute it was reached at equilibrium state where metal cannot be removed from solution more. The quick uptake happened was due to more active sites on moringa oleifera bark were open. It permitted rapidly binding pollutant on the adsorbents. Since the active part became used, the adsorption rates fall down. It can be occurred for reducing active part by metal ions. The elimination activity reduced by about $2-40 \%$ with increasing contact time to reach equilibrium position. It caused from saturation of adsorbent surface with heavy metals followed by adsorption and desorption process after saturation [43].

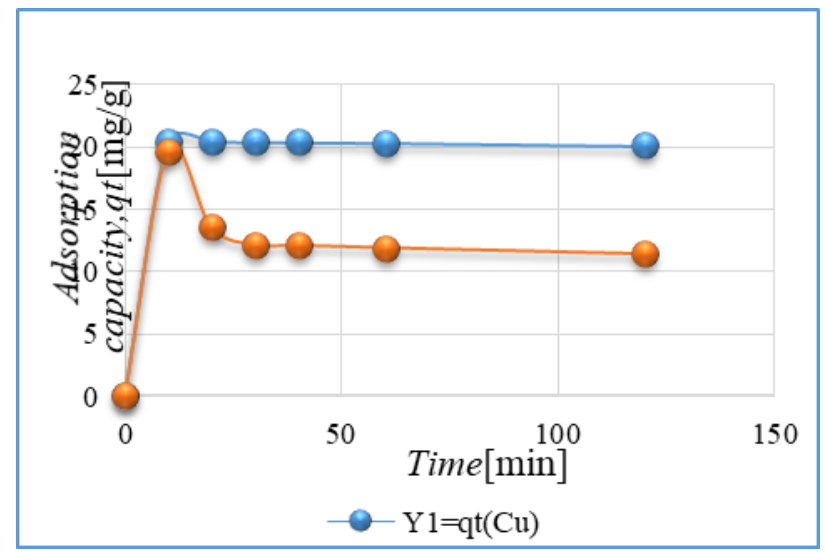

Fig. 10 Effect of time on adsorption capacity of $\mathrm{Cu}^{2+} \& \mathrm{Cd}^{2+}$

\section{G. Effect of Adsorbent Dosage}

The effect of adsorbent dosage was carried out ranging from $5 \mathrm{mg}$ to $50 \mathrm{mg}$ of each activated carbon during removal of heavy metal adsorption from $100 \mathrm{ml}$ aqueous solution as shown in Figure 11. This figure shows that with increasing the adsorbent dosage, the removal of metal ion also improved from $20 \%$ to $100 \%$ for copper and $56 \%$ for cadmium. After reaching at $0.025 \mathrm{~g}$ of adsorbent dosage, the adsorption process also reached equilibrium state. The removal percentage of pollutant improved from aqueous solution with the improving dosage. This can be obtained to have available active part of adsorbents for complexation of heavy metal. Further increasing the adsorbent dose cannot show significant improvement in removal adsorption. This may be occurred due to reach the equilibrium state between binding adsorbate and unabsorbed adsorbate in adsorption process.

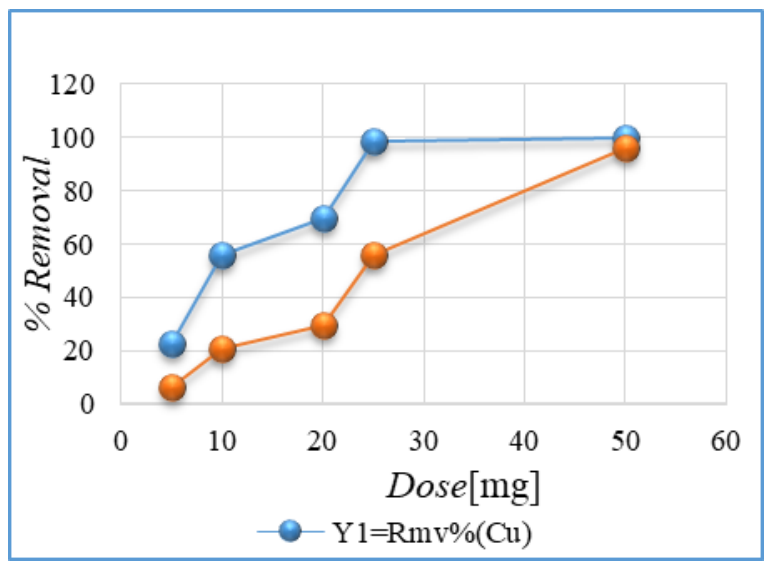

Fig. 11 Effect of dose and on adsorption capacity of $\mathrm{Cu}^{2+} \& \mathrm{Cd}^{2+}$

\section{H. Effect of $P^{H}$}

The adsorption performance of activated carbon can affect by $\mathrm{pH}$ of solution [46]. This studies removal percentage of both metals were conducted ranging $\mathrm{pH} \mathrm{2-12}$ of solution, as shown in Figure 12. The graph shows that with increasing the $\mathrm{pH}$ values, the metal removal percentage also increased and 
at $\mathrm{pH} 11$ maximum removal percentage obtained. If the $\mathrm{pH}$ value was low, the outer surface of adsorbents was gathered with many positive charges, which provided a greater static repulsion force. If $\mathrm{pH}$ increased, the static repulsion forces reduced, and heavy metal adsorption improved. When the $\mathrm{pH}$ value less than 8 the dominant species $\mathrm{Cd}$ (II) is exist $\mathrm{Cd}^{2+}$. At the $\mathrm{pH}$ range of $(9-11), \mathrm{Cd}$ (II) mainly exists in the cationic form of $\mathrm{Cd}_{4}(\mathrm{OH})_{4}{ }^{4+}$. On the other hand, at $\mathrm{pH}$ above the $11, \mathrm{Cd}$ (II) is in the form of $\mathrm{Cd}(\mathrm{OH})_{2}$. The technique of cadmium (II) in adsorption can be conducted by the electrostatic forces. With the increasing the $\mathrm{pH}$ value, the concentration of $\mathrm{H}+$ ion in solution decreases, the negative surface charge will be an increase on the activated carbon above the $\mathrm{pH}(\mathrm{pzc})$ value of (5.4). For this reason, to attract of adsorbing metal cations mainly in the cationic form $\mathrm{Cd}^{4+}$ and they more easily get adsorb onto the adsorbents. The Cd (II) adsorption on activated carbon can be also described by ion exchange mechanism. The main functional groups on the surface of adsorbents are the carboxyl, hydroxyl, methoxyl group which are responsible for ion exchange on to their surface. The mechanism taking place on adsorbents is shown in equation

$$
4-\mathrm{COOH}+\mathrm{Cd}^{4+}=-\left(2(\mathrm{COO}-)_{2}-\mathrm{Cd}^{4+}\right)+4 \mathrm{H}^{+}
$$

At lower $\mathrm{pH}$ less than $5, \mathrm{Cu}$ (II) mainly exits as $\mathrm{Cu}^{2+}$ but at higher $\mathrm{pH}$ range of 7-11 the predominant species of $\mathrm{Cu}$ (II) is $\mathrm{Cu}_{3}(\mathrm{OH})_{4}{ }^{2+}$. At around a $\mathrm{pH}$ of 6 there is a very small fraction of $\mathrm{Cu}_{2}(\mathrm{OH})_{2}{ }^{2+}$ present in the solution. The higher adsorption rate for Moringa oleifera activated carbon at a $\mathrm{pH} 11$ can be explained by the mechanism of electrostatic force. At $\mathrm{pH}>$ $\mathrm{pH}$ (pzc)5.4 for adsorbents, the surface of adsorbent is negatively charged which carry on an electrostatic force between the metal cations $\mathrm{Cu}_{3}(\mathrm{OH})_{4}{ }^{2+}$ and active sites of adsorbent. At a lower $\mathrm{pH}$, the adsorbent surface contains positively charge and $\mathrm{H}+$ ion in the solution inhibit the approach the metal cations and less adsorption occur. On the other hand, the acidic carboxylic group on surface of adsorbents can conduct adsorption of metal ions by ion exchange mechanism which is shown in equation below

$$
-3 \mathrm{COOH}+\mathrm{Cu}_{3}(\mathrm{OH})_{4}{ }^{2+}=3\left(-\mathrm{COO}^{-}-\mathrm{Cu}(\mathrm{OH})^{2+}\right)+3 \mathrm{H}^{+}
$$

At $\mathrm{pH} 2$, the metal adsorption was lower due to present available $\mathrm{H}+$ ions. This $\mathrm{H}+$ ions contested with metal ions for the active sites, hampering to adsorb of $\mathrm{Cu}^{2+}$ and $\mathrm{Cd}^{2+}$ ions with activated carbon. Protonated active part was not capable to adsorb metal due to electrostatic repulsion. As the $\mathrm{pH}$ increased, $\mathrm{H}+$ ions decreased. Therefore, huge negatively charged sites were prepared and metal ions uptake increased by electrostatic attraction.

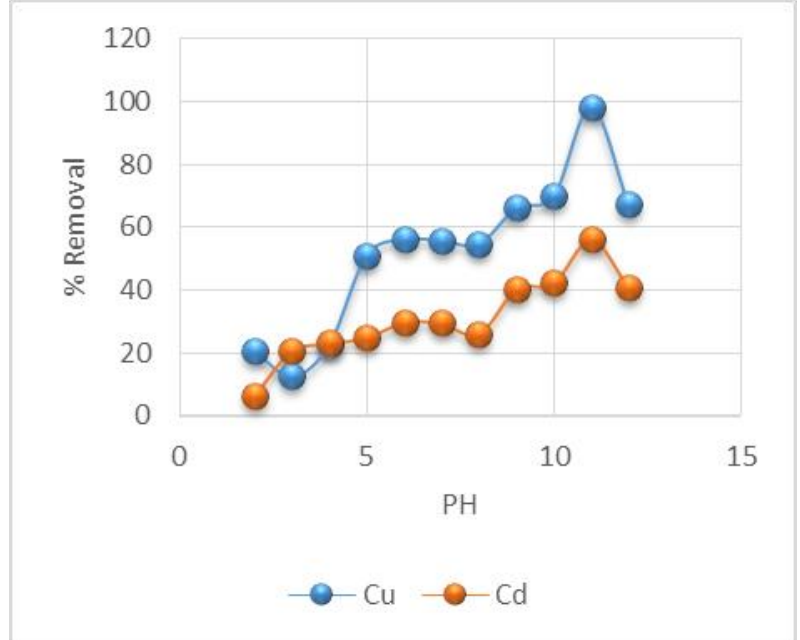

Fig. 12 Effect of $\mathrm{pH}$ on adsorption capacity of $\mathrm{Cu}^{2+} \& \mathrm{Cd}^{2+}$

\section{I.Desorption of Heavy Metals}

The reusability of moringa oleifera was studied by cycling adsorption/desorption process $(\mathrm{Co}=5 \mathrm{mg} / \mathrm{L}, \mathrm{pH} \cong 11, S / L=$ $0.25 \mathrm{~g} \mathrm{~L}-1$ and $\left.t=60 \mathrm{~min}, \mathrm{~T}=25^{\circ} \mathrm{C}\right)$. The studies were conducted by batch desorption technique using $\mathrm{HCl}, \mathrm{H}_{2} \mathrm{SO}_{4}$, $\mathrm{NaOH}$ and $\mathrm{Na}_{2} \mathrm{CO}_{3}$ of $0.1 \mathrm{~N}$ with the metal loaded adsorbent, as shown in Figure 13 and Table 4. Hydrochloric acid performed great desorption efficacy for $\mathrm{Cu}$ (II) $(88.26 \%)$ and Cd (II) (99.13\%). After every adsorption run, activated carbon of Moringa oleifera was separated from the solution by filtration with whatman filter paper and washed with distilled water. It was then dispersed in a solvent $(\mathrm{HCl})$, shaken (200 rpm) for 1 hour and washed with distilled water then dried. Generally, with increasing cycle number, desorption efficiency decreases due to the reduced of adsorption capability as shown in Figure 14 and Table 5. In every cycle, innovative binding sites was decreased which was generated by dilute $\mathrm{HCl}$ treatment. Desorption efficiency of moringa oleifera was calculated from equation (14):

$$
\operatorname{Desorption}(\%)=q_{d} x 100 / q_{e}
$$

Where, $\mathrm{q}_{\mathrm{d}}$ is the mass of the metal ions $(\mathrm{mg} / \mathrm{g})$ desorbed from adsorbents. As well as $\mathrm{q}_{\mathrm{e}}$ is the mass of metal ion $(\mathrm{mg} / \mathrm{g})$ adsorbed onto the adsorbents. The mass of metal ion desorbed, $\mathrm{q}_{\mathrm{d}}(\mathrm{mg} / \mathrm{g})$ is evaluated from this equation

$$
q_{d}=C_{d}
$$

Where, $C_{d}$ is the concentration of the metal ion $(\mathrm{mg} / \mathrm{L})$ left in solution after desorption. The total volume (L) of the solution expressed $\mathrm{V}_{\mathrm{d}}$ and $\mathrm{W}$ is the mass $(\mathrm{g})$ of the adsorbent. 


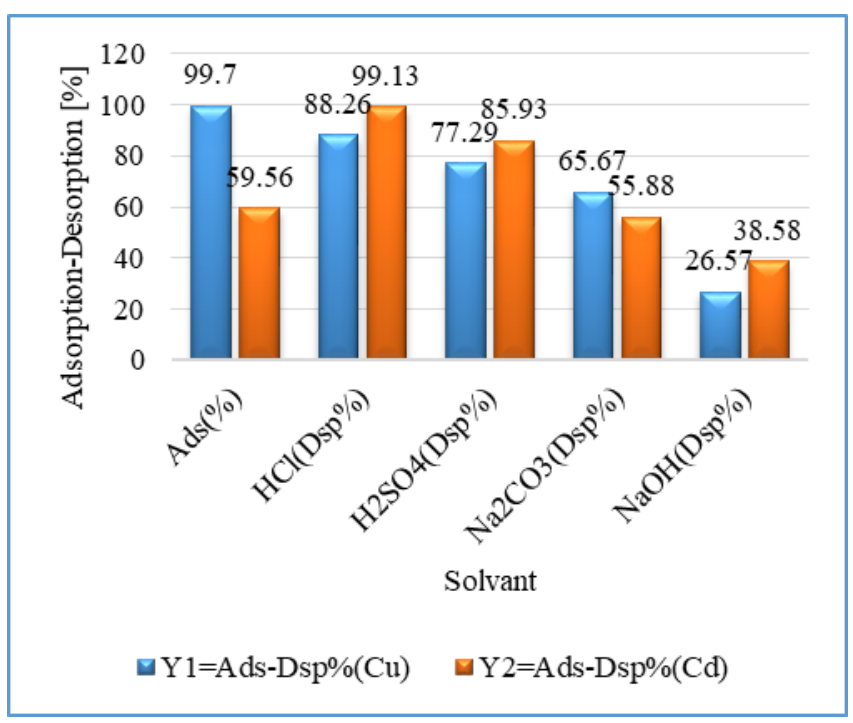

Fig. 13 Adsorption-desorption performance using verities solvents of Moringa oleifera as adsorbent at $C o=5 \mathrm{mg} \mathrm{L}-1, S / L_{\text {ratio }}=0.25 \mathrm{~g} \mathrm{~L}-1$, and T $=25^{\circ} \mathrm{C}$.

TABLE 3 Adsorption desorption percentage of Moringa oleifera activated carbon with different solvents different solvents

\begin{tabular}{cccccc}
\hline Heavy & Adsorption & Desorption & Desorption & Desorption & Desorption \\
Metal & {$[\%]$} & $\mathbf{H C l}[\%]$ & $\mathbf{H}_{2} \mathbf{S O}_{4}[\%]$ & $\mathbf{N a}_{2} \mathbf{C O}_{3}[\%]$ & $\mathbf{N a O H}[\%]$ \\
\hline $\mathrm{Cu}$ & 99.7 & & & & 26.57 \\
$\mathrm{Cd}$ & 59.56 & 99.26 & 77.29 & 65.67 & 38.58 \\
\hline
\end{tabular}

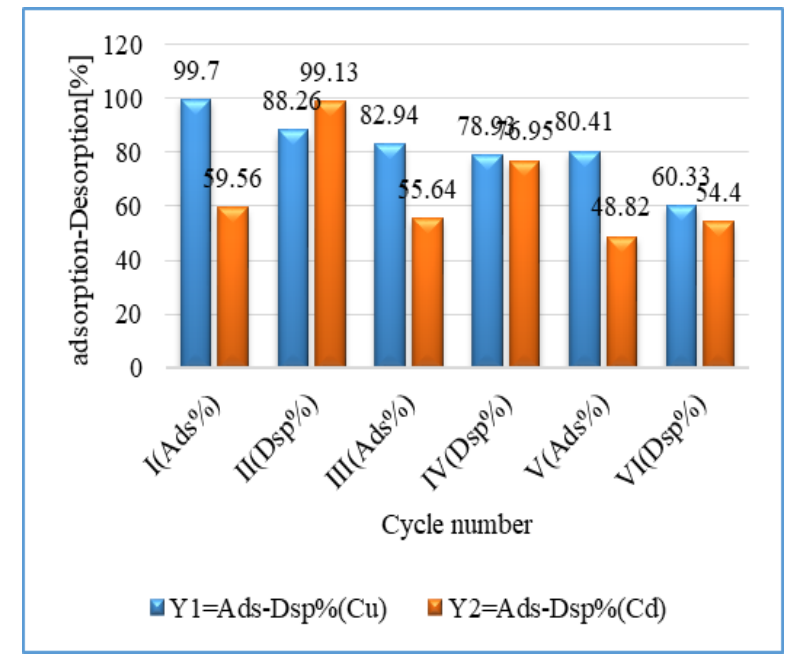

Fig. 14 Adsorption-desorption cycling performance using $0.1 \mathrm{~N} \mathrm{HCl}$ solvents of Moringa oleifera as adsorbent at $C o=5 \mathrm{mg} \mathrm{L}-1, S / L_{\text {ratio }}=0.25 \mathrm{~g} \mathrm{~L}-1$, and $\mathrm{T}=25^{\circ} \mathrm{C}$ 
TABLE 4 Percentage desorption efficiency of Moringa oleifera activated carbon using $0.1 \mathrm{~N} \mathrm{HCl}$ for various cycles

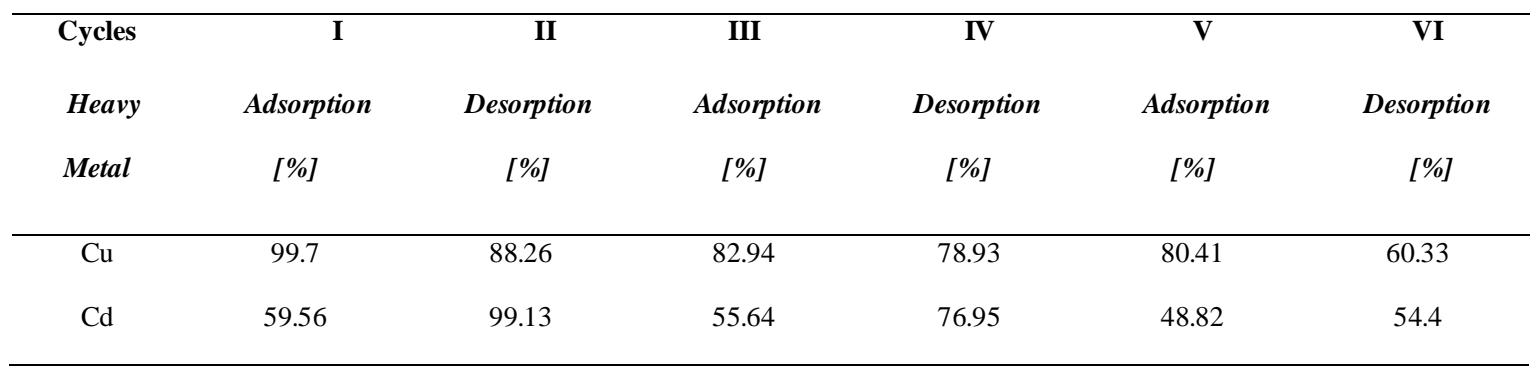

\section{ACKNOWLEDGMENT(S)}

\section{CONCLUSION}

The activated carbon from Moringa oleifera is an effective adsorbent for eliminating toxic metals from wastewater. The adsorptive capacity of the developed carbon depends on the activation process which has impacts on pore size, pore volume and surface area. The adsorption capacity of $20.09 \mathrm{mg} / \mathrm{g}$ for copper and $11.42 \mathrm{mg} / \mathrm{g}$ for cadmium were achieved using activated carbon of Moringa oleifera bark with an acid concentration of $0.5 \mathrm{M} \mathrm{H}_{2} \mathrm{SO}_{4}$. It showed that $\mathrm{Cu}$ was $100 \%$ removed from solution within $10 \mathrm{~min}$ and $\mathrm{Cd}$ also removed $96.32 \%$ from produced wastewater. From the isotherm plot, it was observed that Freundlich plot well fitted with generated data. A pseudo-second order isotherm with a regression correlation $\mathrm{R}^{2}$ of 1 for $\mathrm{Cu}$ and 0.999 of $\mathrm{Cd}$ were well achieved as in contrast to first order model of $0.963(\mathrm{Cu})$ and $0.864(\mathrm{Cd})$. Therefore, a pseudo second order kinetic model is preferred to pseudo-first order model for the kinetics of sorption for $\mathrm{Cu}^{2+}$ and $\mathrm{Cd}^{2+}$ adsorption. The carbon with higher pore volume and surface area was found to be more effective in removing these heavy metal ions. This plant has various chemical constituents. It also has the biological activities including the depletion of metal concentration. Moringa oleifera bark contain the antioxidant properties that are effective to reduce the oxidative stress induced by heavy metal. It was therefore concluded that Moringa oleifera bark acts as a well adsorbent for the treatment of wastewater and reuse it. This should be an encouragement for developing countries.
This research was partial supported by Universiti Sains Islam Malaysia

\section{REFERENCES}

[1] TG. Ellis, "Chemistry of wastewater", Encycl. Life Supp. Sys. (EOLSS), vol. 2, 2004, pp. 1-10.

[2] NT. Abdel-Ghani, El-Chaghaby GA, "Biosorption for metal ions removal from aqueous solutions: a review of recent studies", Int. J. Latest. Res. Sci. Technol., vol. 3, pp. 24-42, 2014.

[3] M. Arafat., S. Mohamed, "Preliminary study on efficacy of leaves, seeds and bark extracts of Moringa oleifera in reducing bacterial load in water", Int. J. Adv. Res., vol. 1, pp. 124-130. 2013.

[4] BZ. Marg., "Hazardous metals and minerals pollution in India: Sources, toxicity and management", A Position Paper, Indian Nat. Sci. Acad., New Delhi, 2011.

[5] A. Demirbas, "Heavy metal adsorption onto agro-based waste materials: a review", J. Hazar. Mater., 157:220-229, 2008.

[6] Ngah WW., Hanafiah M., "Removal of heavy metal ions from wastewater by chemically modified plant wastes as adsorbents: a review," Biores. Technol., 99:3935-3948, 2008.

[7] M. Ahmaruzzaman, "Industrial wastes as low-cost potential adsorbents for the treatment of wastewater laden with heavy metals", Adv. Collo. Interf. Sci., vol. 166, pp. 36-59, 2011.

[8] AM Aljeboree, AN Alshirrifi, AF Alkaim,. "Kinetics and equilibrium study for the adsorption of textile dyes on coconut shell activated carbon", Arab J Chem. 2014

[9] D Pathania , S Sharma ,P Singh , "Removal of methylene blue by adsorption onto activated carbon developed from Fiscus carica Bast”, Arab J Chem, vol. 10, pp. S1445-S1451, 2017.

[10] El Haddad M, R Slimani , R Mamouni , S ElAntri , S Lazar, "Removal of two textile dyes from aqueous solutions onto calcined bones", J Assoc Arab Uni Basic Appl Sci., vol. 14, pp. 51-59, 2013.

[11] R. Joshua, V. Vasu., "Characteristics of stored rain water and its treatment technology using Moringa seeds", Intern. J. Life Sci. Biotechnol. Pharma Res., vol. 2, pp. 155-174, 2013.

[12] Johnstone DW., "Regulation and reality: some reflections on 50 years of international experience in water and wastewater", Inter. J. Water Resour. Devel., vol. 30, pp. 345-354, 2014.

[13] MAM Salleh, DK Mahmoud, WA Karim, A Idris, "Cationic and anionic dye adsorption by agricultural solid wastes: a comprehensive review", Desalination, vol. 280, pp.1-13, 2011.

[14] J. M. Jabar, Y. A. Odusote, "Removal of cibacron blue 3G-A (CB) dye from aqueous solution using chemo-physically activated biochar from oil palm empty fruit bunch fiber", Arab J Chem, 2020.

[15] J. H. Onyuka, R. Kakai, P. Arama, A. Ofulla, "Comparison of antimicrobial activities of brine salting, chlorinated solution and Moringa oleifera plant extracts in fish from Lake Victoria Basin of Kenya", African J. Food, Agri., Nutri. Devel., vol. 13. 2013.

[16] H. Bhuptawat, G. Folkard, S. Chaudhari, "Innovative physicochemical treatment of wastewater incorporating Moringa oleifera seed coagulant", J. Hazar. Mater., vol. 142, pp. 477-482, 2007.

[17] M. Lea, "Bioremediation of turbid surface water using seed extract from Moringa oleifera Lam.(drumstick) tree", Curr. Protoc. Microb., vol. 16, pp. 1G.2.1-1G.2.14., 2010 
[18] M. H. Bichi, "A review of the applications of Moringa oleifera seeds extract in water treatment", Civil Environ. Res., vol. 3, pp. 1-10, 2013.

[19] E. Arnoldsson, M. Bergman, N. Matsinhe, KM. Persson, "Assessment of drinking water treatment using Moringa oleifera natural coagulant", Vatten., vol. 64, pp. 137, 2008

[20] G. Folkard, J. Sutherland, R Al-Khalili., "Water clarification using Moringa oleifera seed coagulant", 2001.

[21] A. P. Meneghel, A. C. Gonçalves, F. Rubio, D. C. Dragunski, C. A. Lindino, L. Strey., "Biosorption of cadmium from water using Moringa (Moringa oleifera Lam.) seeds", Water, Air, \& Soil Pollut, vol. 224, pp. 1383, 2013.

[22] R. N. Bennett et al., "Profiling glucosinolates and phenolics in vegetative and reproductive tissues of the multi-purpose trees Moringa oleifera L.(Horseradish tree) and Moringa stenopetala L.", J. Agri. Food Chem., vol. 51, pp. 3546-3553, 2003.

[23] P. Siddhuraju, K. Becker, "Antioxidant properties of various solvent extracts of total phenolic constituents from three different agroclimatic origins of drumstick tree (Moringa oleifera Lam.) leaves", J. Agri. Food Chem., vol. 51, pp. 2144-2155, 2003.

[24] A. R. Abdulkadir, Z. Suhaili, M. S. Jahan, "Antibacterial screening of different part of Drumstic tree (Moringa oleifera Lam)", J. Chem. Pharm. Res., vol. 7, pp. 500-505, 2015.

[25] L. P. Shank, T. Riyathong, V. S. Lee, S. Dheeranupattana, "Peroxidase activity in native and callus culture of Moringa oleifera Lam", J. Med. Bioeng., vol. 2, 2013.

[26] T. Lockett CCC, E. Louis Grivetti, Cassius. "Energy and micronutrient composition of dietary and medicinal wild plants consumed during drought. Study of rural Fulani, Northeastern Nigeria”, Int. J. Food Sci. Nutri., vol. 51, pp. 195-208, 2000.

[27] A. Ndabigengesere, K. S. Narasiah, B. G. Talbot, "Active agents and mechanism of coagulation of turbid waters using Moringa oleifera. Water Res., vol. 29, pp. 703-710, 1995.

[28] S. Kumar, D. Kumar, N. Singh, B. Vasisht, "In vitro, free radicals scavenging and antioxidant activity of Moringa oleifera pods", J. Herb. Med. Toxic.,vol. 1, pp. 17-22, 2007.

[29] J. Guo, A. Lua, "Preparation and characterization of adsorbents from oil palm fruit solid wastes", 2000.

[30] E. Abechi, C. Gimba, A. Uzairu, J. Kagbu, "Kinetics of adsorption of methylene blue onto activated carbon prepared from palm kernel shell”, Arc. Appl. Sci. Res., vol. 3, pp. 154-164, 2011.

[31] M. Shahinuzzaman et al., "Optimization of extraction parameters for antioxidant and total phenolic content of ficus carica L. Latex from White Genoa cultivar", Asian J. Chem., vol. 31, pp. 1859-1865, 2019.

[32] P. Akhtar, Z. Yaakob, Y. Ahmed, M. Shahinuzzaman, "Ficus species good sources of natural antioxidant drugs", Turk. J. Pharm. Sci., 2019.

[33] D. H. K. Reddy, D. Ramana, K. Seshaiah, A. Reddy, "Biosorption of $\mathrm{Ni}$ (II) from aqueous phase by Moringa oleifera bark, a low cost biosorbent”, Desalination, vol. 268, pp. 150-157, 2011.
[34] J. T. A. Oliveira, S. B. Silveira, I. M. Vasconcelos, B. S. Cavada, R. A. Moreira, "Compositional and nutritional attributes of seeds from the multiple purpose tree Moringa oleifera Lamarck", J. Sci. Food Agri., vol. 79, pp. 815-820. 1999.

[35] K. Azlan, W. N. W. Saime, L. Liew, "Chitosan and chemically modified chitosan beads for acid dyes sorption", J. Environ. Sci., vol. 21, pp. 296-302, 2009.

[36] M. A. Ahmad., R. Alrozi, "Optimization of preparation conditions for mangosteen peel-based activated carbons for the removal of Remazol Brilliant Blue R using response surface methodology", Chem. Eng. J., vol. 165, pp. 883-890, 2010.

[37] K. Nuithitikul, S. Srikhun, S. Hirunpraditkoon, "Influences of pyrolysis condition and acid treatment on properties of durian peelbased activated carbon", Biores. Technol., vol. 101, pp. 426-429, 2010.

[38] G. Mehetre, V. Pande,, \& P. Kendre,, "Isolation and characterization of bionanofibers from Moringa oleifera10 R. K AND U. J gum as a platform for drug delivery", Nanoscience and Nanotechnology Research, Science and Education Publishing, vol. $3(1)$, pp. $1-5,2015$

[39] K. Santhi, , \& R. Sengottuvel, "Functional group analysis of Moringa concanensis Nimmo (Moringaceae) by FTIR spectrum", IOSR Journal of Pharmacy, vol, 7(1), pp. 28-33, 2017.

[40] T. A. Khan, M. Nazir, I. Ali., \& A. Kumar, "Removal of chromium (VI) from aqueous solution using guar gum-nano zinc oxide biocomposite adsorbent" Arabian Journal of Chemistry, vol. 10(2), pp. 2388-2398, 2017.

[41] F. Ahmad, W. M. A. W. Daud, M. A. Ahmad, and R. Radzi, "The effects of acid leaching on porosity and surface functional groups of cocoa (;eobroma cacao)-shell based activated carbon", Chemical Engineering Research and Design, vol. 91, no. 6, pp. 1028-1038, 2013.

[42] Homagai PL., Ghimire KN., Inoue K., "Adsorption behavior of heavy metals onto chemically modified sugarcane bagasse", Biores. Technol., vol. 101, pp. 2067-2069, 2010.

[43] N. Azouaou, Z. Sadaoui , A. Djaafri , H. Mokaddem., "Adsorption of cadmium from aqueous solution onto untreated coffee grounds: Equilibrium, kinetics and thermodynamics", J. Hazar. Mat., vol. 184, pp. 126-134, 2010.

[44] J. Iriondo-Alberdi, K. Laxmi-Reddy, B. Bouguerne , C. Staedel., I. Huc, "Cellular Internalization of water-soluble helical aromatic amide foldamers", ChemBioChem, vol. 11, pp. 1679-1685,2010.

[45] M. A. Ahmad, R. Alrozi, "Removal of malachite green dye from aqueous solution using rambutan peel-based activated carbon: Equilibrium, kinetic and thermodynamic studies", Chem. Eng. J., vol. 171, pp. 510-516, 2011.

[46] A. N. Khairul, H. M. Sukri, and F. Ahmad, "Removal of methylene blue from aqueous solution using cocoa (Theobroma cocao) nibbased activated carbon treated with hydrochloric acid", Malaysian J. Fund. App. Sci. vol.14, no. 2, pp. 193-197, 2018. 